Thorax (1963), 18, 350

\title{
The diagnosis of lung cancer by examination of sputum
}

\author{
K. F. W. HINSON AND S. W. A. KUPER \\ From the Brompton Hospital, London, S.W.3
}

The value of sputum examination in the detection of lung cancer has been established by several workers. We have attempted to assess at this hospital the usefulness of examining routine sputum samples submitted for cytology and to investigate several aspects of the procedure.

\section{MATERIAL AND METHODS}

All the sputum samples were from patients attending a chest hospital, so that lung or heart disease was nearly always present and cancer of the lung suspected. The work extended over approximately nine months of 1960-61 and included the winter with its seasonal increase in bronchitis.

No special efforts were directed to an exhaustive search in individual patients, unless requested by the clinician, and the material examined consisted of routine sputum samples submitted to the pathology department. Despite requests for careful early morning collection, a certain number consisted, as usual, of saliva or of sputum mixed with food, toothpaste, etc.

Two pathologists co-operated, one with several years' experience of this work, the other having spent a month or two familiarizing himself with sputum cytology. No preservative was added to the collection bottles, but material was examined as soon as possible, usually within a few hours.

The sputum was decanted into a Petri dish and examined against a black background. When present, white threads or blood-flecked streaks were selected for examination.

The sample chosen was placed on a clean microscope slide, and a drop of $1 \%$ aqueous methylene blue was added. After thorough mixing, a large coverslip was placed on the slide and gently pressed until the sputum layer was of suitable thickness. Similar methods using unfixed material have been described by Schuster (1955), Jennings and Shaw (1953), and McCormack, Hazard, Belovich, Effler, and Groves (1961).
A comparison has been made between methylene blue preparations and stains involving fixation, and it is possible that methylene blue methods may be a little more sensitive (Philps, 1954). We did not, however, compare the two methods. The methylene blue method has the serious disadvantage of not providing permanent preparations, but this was partly overcome by photographing all positive results. There are several advantages: cell morphology is especially clear in unfixed material, thick preparations are possible because pressure on the coverslip can be used to clarify the picture when a microscopic field looks suggestive, and when the pathologist is in doubt he can readily make additional preparations from the sputum which is still fresh.

We have not as yet had satisfactory results with liquefaction techniques using trypsin (Farber, 1961) or hyaluronidase (Hattori, Matsuda, and Morimoto, 1959) or with acridine orange fluorescence (Bertalanffy, 1961).

Each of us made two slide preparations of every sputum, and a note was kept of who had the first choice. We each spent up to five minutes searching each slide, unless definite tumour cells were found sooner. If the first slide was found to be 'positive', the second was not examined.

All material was presented without any other identification than a serial number, so that bias was removed as far as possible, and each of us recorded his findings separately, before any comparison was made of the day's results. We reported each slide as 'positive', 'negative' or, rarely, 'doubtful', and a note was kept of whether it had been necessary to search the second slide. When tumour cells were present, we tried to identify the cell type.

This investigation has been confined to sputum produced normally. As yet we have no experience of examining sputum produced under the stimulus of inhalants, which have been claimed to improve the chances of cancer cell detection (Bickerman, 
Sproul, and Barach, 1958 ; Fontana, Carr, Woolner, and Miller, 1962).

\section{RESULTS}

From 541 patients 1,671 sputum samples were examined. Of these patients 229 had carcinoma of the bronchus, proved histologically, or in whom the clinician considered the diagnosis established at the time of this analysis. Ten patients had some other pulmonary malignant disease and 302 patients had diseases other than cancer.

In the 10 patients with secondary neoplasm in the lung, neither observer found tumour cells. Other workers have proved more successful. Rosenberg, Spjut, and Gedney (1959) found cancer cells in $38 \%$ of 50 patients with metastatic lung cancer ; Parker and Reid (1960) found cells in $73 \%$ of 30 such patients.

In considering all the findings that are listed below, it is important to remember that the data refer only to the special conditions under which this investigation was carried out.

The results of examination of all sputum samples from patients with carcinoma of the bronchus are shown in Table I. In 77 patients the diagnoses

\section{TABLE I}

RESULTS OF ALL SPUTUM SAMPLES IN PATIENTS WITH CARCINOMA OF THE BRONCHUS

\begin{tabular}{lll} 
Type & No. of Patients & Positive (\%) \\
\hline Squamous carcinoma & 70 & 67 \\
Adenocarcinoma & 26 & 42 \\
Oat-cell carcinoma & 14 & 36 \\
Undifferentiated carcinoma & 42 & 46 \\
Not known & 77 & 71 \\
Total & 229 & 60
\end{tabular}

were made on clinical and radiological grounds; the cell type could not be determined because neither surgery nor necropsy was performed. Of the remainder, nearly half had squamous-cell carcinomas, and in this type over two-thirds had tumour cells found in the sputum.

If one considers the findings in the first sputum sample from each of the 229 patients with carcinoma of the bronchus (Table II), it is evident that $44 \%$ of squamous carcinomas would have been detected if only a single sputum sample had been examined.

T A B LE I I

RESULTS OF FIRST SPUTUM SAMPLES IN PATIENTS WITH CARCINOMA OF THE BRONCHUS

\begin{tabular}{lll} 
Type & No. of Patients & Positive (\%) \\
\cline { 1 - 2 } Squamous carcinoma & 70 & 44 \\
Adenocarcinoma & 26 & 27 \\
Oat-cell carcinoma & 14 & 14 \\
Undifferentiated carcinoma & 42 & 29 \\
Not known & 77 & 43 \\
Tota & 229 & 37
\end{tabular}

T A B LE I I I

COMPARISON OF BRONCHOSCOPY RESULTS AND EXAMINATION OF SPUTUM SAMPLES

\begin{tabular}{llll} 
Bronchoscopy & $\begin{array}{l}\text { No. of } \\
\text { Patients }\end{array}$ & $\begin{array}{l}\text { Sputum } \\
\text { Positive (\%) }\end{array}$ & $\begin{array}{l}\text { First Sputum } \\
\text { Sample } \\
\text { Positive (\%) }\end{array}$ \\
\hline Positive & 60 & 58 & 35 \\
Negative & 38 & 71 & 42 \\
Not done & 131 & 60 & 37 \\
Total & 229 & 61 & 38
\end{tabular}

Table III shows a comparison of bronchoscopy results and an examination of sputum samples. In 98 of these patients bronchoscopy was done. Sputum examination was clearly most useful in the 38 patients in whom bronchoscopy was unhelpful, for $42 \%$ of these could have been found by examining one sputum sample, and $71 \%$ were diagnosed from all the samples sent. Of the 131 patients in whom bronchoscopy was not done (usually because of advanced disease), $60 \%$ had tumour cells in the sputum.

FIRST SELECTION OF MATERIAL BY OBSERVER 1 OR 2 Observer 2 selected his sample first approximately twice as often as observer 1 . This difference was not intended and was determined by the pressure of other routine duties.

Of the total 162 samples from which observer 1 had first choice (Table IV), we were in agreement on the 47 that were positive and the 135 that were negative. In those samples where we differed,

TA B LE I V

SAMPLES FROM WHICH OBSERVER 1 HAD FIRST CHOICE

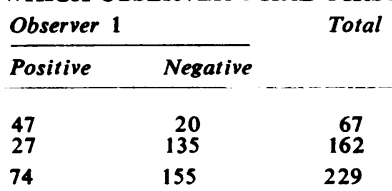

observer 1 appears a little more efficient in selecting material or in finding cancer cells, but the difference is not statistically significant.

T A B LE V

SAMPLES FROM WHICH OBSERVER 2 HAD FIRST CHOICE Observer 1

\begin{tabular}{cccc} 
& Positive & Negative & \\
\cline { 2 - 4 } Observer 2 & 87 & 44 & 131 \\
Positive & 87 & 297 & 340 \\
Negative & 43 & 341 & 471 \\
Total & 130 &
\end{tabular}

In the samples from which observer 2 had first choice (Table V) no real difference is evident between the two observers.

VALUE OF EXAMINING TWO SLIDES FROM EACH SAMPLE Samples were examined in duplicate in 1,667 instances. Observer 1 found tumour cells in 
the first or second specimen in 254 samples. He found these cells only in the second slide in 34 instances, i.e., $14 \%$. The second observer found tumour cells only in the second slide in 39 instances, i.e., $16 \%$.

The discovery of cancer cells in sputum is partly dependent on chance selection of a suitable portion. An average of $15 \%$ of the successes recorded were due to examining a second slide when no tumour cells were present in the first.

OBSERVER VARIATION The success of each observer in detecting cancer cells in the sputum in patients with carcinoma of the bronchus can be assessed from the number of sputum samples found to be positive, or from the number of patients whose sputum revealed the diagnosis.

On sputum samples from patients with a carcinoma of the bronchus (Table VI) there is

TABLE VI

OBSERVER VARIATION IN SPUTUM SAMPLES FROM PATIENTS WITH CARCINOMA OF THE BRONCHUS

\begin{tabular}{llllll} 
& \multicolumn{2}{l}{$\begin{array}{l}\text { Histologically } \\
\text { Proven }\end{array}$} & & \multicolumn{2}{c}{$\begin{array}{l}\text { Not Histologically } \\
\text { Proven }\end{array}$} \\
\cline { 2 - 3 } \cline { 5 - 6 } \cline { 5 - 6 } & Total & Positive & & Total & Positive \\
\hline Observer 1 & 448 & $139(31 \%)$ & & 242 & $63(26 \%)$ \\
Observer 2 & 552 & $166(30 \%)$ & & 283 & $78(28 \%)$
\end{tabular}

clearly close agreement between the two observers, and there is little difference between the patients whose diagnosis had been histologically proved and those in whom it was based on clinical grounds.

In patients with carcinoma of the bronchus in whom sputum samples yielded positive results (Table VII), observer 2 was slightly more success-

TABLE VII

O3SERVER VARIATION IN PATIENTS WITH CARCINOMA OF THE BRONCHUS WHOSE SPUTUM SAMPLES YIELDED POSITIVE RESULTS

\begin{tabular}{llllll} 
& \multicolumn{2}{l}{$\begin{array}{l}\text { Histologically } \\
\text { Proven }\end{array}$} & & \multicolumn{2}{l}{$\begin{array}{l}\text { Not Histologically } \\
\text { Proven }\end{array}$} \\
\cline { 2 - 3 } & Total & Positive & & Total & Positive \\
\hline $\begin{array}{llllll}\text { Observer 1 } \\
\text { Observer 2 }\end{array}$ & 156 & $64(41 \%)$ & & 77 & $39(51 \%)$ \\
\hline
\end{tabular}

ful in identifying the patients with cancer. Both observers found a greater proportion of those in whom there was no histological proof, which probably reflects partly the greater number of patients with advanced inoperable disease in whom bronchoscopy was considered undesirable.

One or both observers found cancer cells in the first sample examined in $37 \%$ of patients with carcinoma of the bronchus. This figure rose to $53 \%$ after examination of two samples, $60 \%$ after examination of three, $68 \%$ after examination of four, and $71 \%$ after examination of five samples.
It is apparent that the proportion of positive results rose steadily until four sputum samples had been examined. The addition of the fifth sample added only $3 \%$ to our recovery rate. It is perhaps necessary to stress again that this statement refers only to the conditions under test, four samples examined separately by two trained observers, each preparing two slides and each spending up to five minutes on each slide. (Farber (1961) recommends examining five sputum samples in order to detect most cases of lung cancer.)

TABLE VIII

IMPROVED SKILL WITH PASSAGE OF TIME

\begin{tabular}{llll} 
& & \multicolumn{2}{c}{ Sputum Samples } \\
\cline { 3 - 4 } & & First Half & $\begin{array}{l}\text { Second } \\
\text { Half }\end{array}$ \\
\hline Observer 1 & Positive & $114(30 \cdot 7 \%)$ & $90(27 \cdot 2 \%)$ \\
& Negative & 236 & 221 \\
& Doubtul & 21 & 20 \\
Total & 371 & 331 \\
Observer 2 & Positive & $91(23 \cdot 4 \%)$ & $153(33 \cdot 2 \%)$ \\
& Negative & 265 & 278 \\
& Doubtful & 33 & 30 \\
& Total & 389 & 461
\end{tabular}

It is clear from Table VIII that the skill of observer 1 did not alter significantly during the period of the trial. The second observer, the less experienced, gained additional skill, or possibly confidence, after the passage of a few months.

TABLE IX

POSITION OF GROWTH IN THE BRONCHIAL TREE

\begin{tabular}{lcl}
$\begin{array}{l}\text { Tumours } \\
\text { Peripheral }\end{array}$ & Total & $\begin{array}{l}\text { Positive by } \\
\text { Eithe: Observer }\end{array}$ \\
\hline Central & 36 & 22 \\
Not known & 90 & 55 \\
& 107 & 63
\end{tabular}

Table IX shows the position of the growth in the bronchial tree. The peripheral growths are those in which sputum cytology is most useful, for they are beyond the reach of the bronchoscope. Of the 36 patients known to have peripheral growths, nearly two-thirds were found to have exfoliated cancer cells in the sputum.

IDENTIFICATION OF THE TYPE OF TUMOUR Histological identification of the cell type was possible from bronchial biopsy, lobectomy, pneumonectomy, or post-mortem examination in about two-thirds of the patients presumed to have carcinoma of the bronchus. In these patients, a comparison was made between the actual cell type and that accorded the exfoliated cells in the sputum. In squamous-cell carcinoma, the most frequent tumour present, our findings concurred with the histological type about three times out of four (34 out of 46 in agreement for observer 1 ; 38 out of 54 in agreement for observer 2). The 
concurrence was less with the other types of tumour, the chances of agreement being just over $50 \%$, but the numbers available in these groups are very small ( 9 out of 13 for observer $1 ; 5$ out of 10 for observer 2).

The question of false positive results is a serious matter if the clinician is to place reliance on the results of sputum cytology.

In the 302 patients thought by the clinician not to have cancer at the time of analysis, we reported the presence of cancer cells in 12 patients. Since the compilation of the data, three of these have been shown to have a carcinoma of the lung, but the other nine patients do not as yet reveal any signs of cancer. Of these nine patients, only one was repeatedly reported as positive, the other eight having been reported positive only once. Our inaccuracy, therefore, did not exceed $3 \%$, and may well be less.

The presence of cancer cells in sputum can be due to exfoliation of cells from tumours in the upper respiratory tract or mouth, but these cannot be regarded as 'false positives'. Apart from lack of experience in recognizing artefacts, actual error is due usually to squamous metaplasia in long-standing bronchiectatic and tuberculous cavities, or following lobectomy or pneumonectomy. Furthermore, for a period of one to two weeks after bronchoscopy, shreds of mucosa may produce alarming artefacts, sometimes resembling adenocarcinoma. Cilia may provide a clue to their identity.

\section{COMMENT}

The usefulness and reliability of sputum examination in the diagnosis of lung cancer has been well established. Trained observers are essential, and they must be prepared to spend long periods in intense scrutiny. This pinpoints the desirability of careful sputum collection and reasonable selection of patients. The procedure can be most helpful in cases of strong clinical presumption of lung cancer but in whom bronchoscopy has been unsuccessful or is deemed undesirable. In such patients it is worth while examining a large number of sputum samples.

Satisfactory techniques for liquefaction of sputum without cellular damage and concentration of the cells by centrifugation would be of great assistance. The tumour cells might be expected to concentrate in a definite layer of the cell button. Histological sections of the button may enable one to scan all the layers from a large sputum sample in a fairly short time. Efforts to elaborate such a technique are in hand. It is hoped to improve our performance by the combination of such a technique with an inhalation method that stimulates sputum secretion.

Our degree of success might have been greater had we known the clinical and other details at the time of examination. This may be necessary in routine clinical practice, but for the purpose of this particular inquiry it was undesirable.

\section{SUMMARY}

From 541 patients 1,671 routine sputum samples were examined. Of these patients, 229 were suffering from carcinoma of the bronchus. Two pathologists each made two separate wet preparations from each sample and examined them independently, without any information about the patients. Their degree of success in finding tumour cells was very similar, and repeated examination revealed these cells in about two-thirds of patients with carcinoma of the bronchus. False positives were recorded in under $3 \%$ of samples, and only in one patient was a false positive reported on more than one occasion.

We are greatly indebted to Mr. P. M. Payne, Director of the South Metropolitan Cancer Registry, Sutton, Surrey, for his advice and assistance in analysing the results and compiling the tables. We would also like to thank Mr. R. A. Sellwood, Department of Surgery, Postgraduate Medical School of London, Hammersmith Hospital, for his invaluable assistance in compiling the data, and Mr. A. Davies, of the above department, for helping with the abstraction of the clinical records.

\section{REFERENCES}

Bertalanffy, F. D. (1961). Diagnostic reliability of the acridine orange fluorescence microscope method for cytodiagnosis of cancer. Cancer Res., 21, 422.

Bickerman, H. A. Sproul, E. E., and Barach, A. L. (1958). An aerosol method of producing bronchial secretions in human subjects: A clinical technic for the detection of lung cancer. Dis. Chest, 33, 347.

Farber, S. M. (1961). Clinical appraisal of pulmonary cytology. J. Amer. med. Ass., $175,345$.

Fontana, R. S., Carr, D. T., Woolner, L. B., and Miller, F. K. (1962) An evaluation of methods of inducing sputum production in patients with suspected cancer of the lung. Proc. Mayo Clin. 37, 113.

Hattori, S., Matsuda, M., and Morimoto, K. (1959). Studies on the cytologic diagnosis of lung cancer. Med. J. Osaka Univ., 10, 139 .

Jennings, R. C., and Shaw, K. M. (1953). The value of cytological examination of the sputum in the diagnosis of carcinoma of the bronchus. Thorax, 8, 288 .

McCormack, L. J., Hazard, J. B., Belovich, D., Effler, D. B., and Groves, L. K. (1961). Cytological use of "wet films" in the detection of carcinoma of the lung. Cancer (Philad.), 14, 1139.

Parker, R. E., and Reid, J. D. (1960). Five-year survey of results of cytological examination for lung cancer. $N$.Z. med. J., $59,68$. Philps, F. R. (1954). The identificat
sputum. Brit. J. Cancer, 8, 67.

Rosenberg, B. F., Spjut, H. J., and Gedney, M. M. (1959). Exofoliative cytology in metastatic cancer of the lung. New Engl. J. Med.,

261, 226.
Schuster, N. (1955). Cancer cells in the sputum. Tubercle (Lond.), 36,350 . 